\title{
Regional Policy of Russia in the Far East: Why Does It Go Wrong and What Is Apparently Seceded
}

\author{
A. B. Volynchuk ${ }^{1}$, S. K. Pestsov ${ }^{2}$, L. E. Kozlov² \& Ya. A. Volynchuk ${ }^{3}$ \\ ${ }^{1}$ Institute of History, Archeology and Ethnography of the Peoples of the Far East, the FEB RAS (Far Eastern \\ Branch of the Russian Academy of Science), Russia \\ ${ }^{2}$ Far Eastern Federal University, Vladivostok, Russia \\ ${ }^{3}$ Vladivostok State University of Economics and Service, Vladivostok, Russia \\ Correspondence: A. B. Volynchuk, Institute of History, Archeology and Ethnography of the Peoples, the Far \\ East of the FEB RAS (Far Eastern Branch of the Russian Academy of Science), 89, Pushkinskaya street, \\ Vladivostok, 690001, Ruasia. E-mail: info@ores.su
}

Received: August 2, $2018 \quad$ Accepted: September 13, $2018 \quad$ Online Published: October 17, 2018
doi:10.5539/jpl.v11n4p1
URL: https://doi.org/10.5539/jpl.v11n4p1

The study was carried out with the financial support of the Russian Foundation for Basic Research in the framework of the scientific project No. 18-014-00012.

\begin{abstract}
The main subject matter in this article is the development policy of the Russian Far East as one of the aspects (constituent elements) of the regional development of the Russian Federation declared and implemented by the country's leadership since the mid-1990s. The Russian experience of regional policy related to the development of the Far East is of scientific and practical interest. The analysis of modern regional policy allows us talking about a new content interpretation, formation of basic approaches, principles in the development of the Russian Far East. The main features and peculiarities of this policy are considered by the authors in the context of a discussion about the so-called new paradigm of regional policy that is unfolding in recent years. The article analyzes the strengths and weaknesses of the new regional policy based on the provision of tax and other benefits to business entities, and evaluates its effectiveness.
\end{abstract}

Keywords: regional policy, regional growth strategy, territorial development, special economic area, priority development area, PDA, Far East

\section{Introduction}

The Far East (RFE) occupies $36 \%$ of the territory of Russia, where only $4 \%$ of its population live. The government of Russia has been fighting for a century and a half - with the tsar, the Communists and Putin - to develop this macroregion and make it, at least, to provide itself. This story prompts to think about whether the center is able in principle to develop such a vast territory with a harsh climate and a rare population and make it part of the overall economic area of the country. In our opinion, it is appropriate to compare the RFE only with Canada and Western China with the complexity of the tasks. The applied relevance of this story is related to the prospects of the Russian economy in the XXI century. The revenues received from the export of hydrocarbons and non-ferrous metals account for about half of Russia's budget; their share has reached $80 \%$ in some years. The explored and easily retrievable reserves will soon be exhausted, and new mine sites are located in the east of the country. And of course, the less the resident population lives there, the more expensive will be their commissioning and the lower will be the profit.

In our opinion, the entire list of tasks of state regional policy formulated in the introduction of the "Socio-Economic Development Strategy for the Far East and the Baikal Region for the Period Until 2025", maybe reduced to the following political denominator: 1) residence in the RFE of a permanent population in an amount sufficient to repel the claims of foreign states to this territory, 2) the standard of living of this population sufficient to maintain its political loyalty to the center, 3) infrastructure and production capacities sufficient for the cost-effective exploitation of natural resources of the RFE in the national interest (Kozlov \& Volynchuk, 2016). 
The statistical and political results of an active regional policy in the RFE have appeared to be ambiguous of the last decade. In any case, there has been no noticeable improvement in the state of the regional economy and demography. Moreover, since 2014 to the present, the implementation of regional construction projects in Russia has been complicated due to the negative growth of the national economy, a reduction in budget revenues and foreign sanctions against Russia. This decade was summed up by a devastating public criticism of the prosecutor's office at the turn of 2017-2018, which noted the failure of most of the relevant events. In this article, we will try to answer the question why Russia's regional policy in the Far East receives a much smaller result than the center counts on. We are also interested in the extent to which this result is nevertheless achieved, that is, what real result the foreign observers may expect from the moment when Moscow once again comes up with the slogans and ideas for the accelerated development of the RFE for, for example, 10 years.

\section{Method}

As a methodology, we rely on the theory of James C. Scott specified in "Seeing Like a State". When the government tries to control the territorial and the general socio-economic development of the country, it schematizes in its plans and programs the diversity of regional structures, ignores local management practices that have developed over decades and centuries for certain reasons, experiences in general a modern self-confidence about reforms and therefore often suffers failure (Scott, 1998). Although, we do not completely deny the possibility of etatism in regional politics, since the history of Russia gives several examples of its success, but Scott's explanations are well suited for the post-Soviet Russia. We also involved in our study the theory of a new political economy about "rent-seeking behavior", since most of the regional policies in Siberia and the RFE are accompanied by the facts of corruption and are implemented in the export interests of specific Russian corporations (Tullock, 2005).

There is a long-standing discussion on the content of the term "regional policy" in the scientific and information space. We understand this as a set of methods, legislative and other regulatory legal acts, development plans and programs developed and implemented by the competent state authorities, with an aim of forming a given territorial structure of the economy and society (Kozlov \& Volynchuk, 2016). At the same time, we refer to such measures not only the social and economic one, but also personnel, party, defense, diplomatic and others, if they are aimed at transforming the territorial structure of the region.

In this study, we compare the tasks and forecasts of regional development with the actual scope of activities performed and the investments made. Our main sources are as follows:

1) Federal target programs, regional and sectoral development strategies;

2) Federal laws establishing special conditions for doing business in the RFE;

3) Statements by the Ministry of Regional Development about the forthcoming private investments. They are mainly made based on the results of international political and economic forums in Vladivostok;

4) Transcripts of the sessions of the Government of the Russian Federation on regional policy issues;

5) Statistical collections of Rosstat on the socio-economic results of the regions;

6) Statements of the Prosecutor's Office and the Accounts Chamber of the Russian Parliament on the number and quality of the events executed within the framework of the targeted programs and instructions of the President of Russia.

\section{Literature Review}

The RFE development interests, first of all, the Russian authors: geographers, economists, political scientists. We note the most famous specialists who have not only the experience in scientific research, but also in the development of state documents for the territorial development.

Olga Kuznetsova believes that the state policy and the quality of governance are important, but not the main factors for the regional development, yielding to objective factors: economic and geographical position, natural conditions and resources, etc. (Kuznetsova, 2013). In recent years, Moscow has been actively trying to attract foreign investors to the RFE, and these efforts have led to some increase in FDI (Foreign Direct Investments), but mostly attracted Russian, rather than foreign firms to the RFE (2018) (Kuznetsova, 2018).

Natalia Zubarevich highlights the leveling, stimulating and geopolitical priorities of regional policy (Zubarevich, 2016). If in the 1990's Russia followed a leveling priority, then in the 2000s the geopolitics prevailed, when the state aimed, first of all, to keep the territory, including the RFE. This is the most costly kind of regional policy. It badly encourages the private firms to follow the state investments. After 2014, the main foreign partner of the RFE was China, and now it would firmly dictate its game rules to Russia. 
Pavel Minakir and Olga Prokapal prove that the RFE achieved the best economic results in those periods when the state combined the non-economic goals and the use of centralized resources with the goals of endogenous reproduction in the region itself. The least successful were the periods when the state pursued exclusively the colonial goals of extracting maximum utility in the region, with minimal support for endogenous development factors. Today, Moscow combines the colonial exploitation of transit capacities and natural resources of the RFE with the restoration of a diversified economic complex here (Pavel \& Olga, 2017).

The European, American and Asian authors have also a stable interest in Russia's regional policy in the East. In the last decade, several great works have been published based on a good knowledge of the RFE empirics. As a rule, the scientists from Vladivostok or Khabarovsk are involved in their preparation, which provides a better understanding of local specifics by the authors.

The book of Fiona Hill and Clifford Gaddy "The Siberian Curse" is of particular importance among this literature (Hill \& Gaddy, 2003). It puts the most important methodological issues about the relationship between the regional economy and the climate and about the importance of political coercion in the primary development of the East of Russia. Their main idea is that the harsh climatic conditions of Siberia make it unprofitable to settle it on an ongoing basis. Based on the geopolitical interests, through huge efforts, sacrifices and costs, the USSR has developed this region to some extent, but the population will emigrate from here and the main resources will be developed by the shift method in the free market conditions.

The team of authors led by Jing Huang and Alexander Korolev explored the geoeconomics and geopolitics of "Pacific Russia", the main factors of the region's development and the mechanisms that allow it being integrated into Asia (Huang \& Korolev, 2017). They argue that the "turn to the East" is important for the diversification of the Russian economy, but it is far from complete. In their opinion, Russia will benefit from the fact that the "turn to the East" will be truly international and multilateral. In any case, Russia's integration into the APR (Asia-Pacific Region) has gotten off the mark, and the crisis between Russia and the West has only accelerated it.

Silvana Malle and Julian Cooper emphasize that the defense strengthening and the development of the East of Russia have become the top priorities of V. Putin's rule. The authors note the extreme centralization of Russia's regional policy. Without denying its possibilities, they consider a centralized policy to be the most costly. Russia's regional policy would be more effective, if the center gave the regional authorities more authority in selecting development projects and granting benefits (Malle \& Cooper, 2014).

The central problem of the monograph "Russia's Far East. New Dynamics in the Asia Pacific and Beyond" prepared by Rensselaer Lee and Artyom Lukin is the growing economic and political influence of China on Russia as a whole and the RFE in particular (Lee \& Lukin, 2016). The authors draw the US attention to this process. They advise the United States to overcome disagreements with Russia and to join the RFE development, until the Russian economy has become completely dependent on China.

The team led by Helge Blakkisrud and Elana Wilson Rowe studied the RFE in the context of Russia's general aspiration to economic development and security (Blakkisrud \& Rowe, 2018). According to the authors, the key political initiatives aimed at the RFE development were formulated long before the crisis in relations between Russia and the West, as well as Russia and China began a rapprochement long before 2014. Some diplomatic successes in the "turn to the East" were achieved, however, Moscow's financial resources were limited, so its investments in the RFE development were steadily declining and did not have much success in the post-Crimean period.

Iacopo Adda, based on the geopolitical theory of the Heartland, notes that so far Moscow has been unable to develop an effective policy in the RFE, but the RFE will remain a strategic priority in the coming decades. In general, we should wait for Russia to move from the category of a European sate, with possessions in Asia to a fundamentally different geopolitical state associated with changes in the mentality of Russians, the Kremlin's social and economic policies, and Moscow's diplomatic strategies (Adda, 2015).

\section{Results}

The issue of causes, scale and nature of the difficulties that befell the Russian economy in 2014-2016 is debating. Assessing the external factors of recession of the Russian economy, Yevsey Gurvich and Ilya Prilepskiy come to the conclusion that Western sanctions have indeed had a negative impact on the Russian economy, leading to a loss of 2.4\% of GDP on the horizon of 2017, but the fall in world oil prices has had greater importance and has led to the loss of $8.5 \%$ of GDP: "The difference in the impact of two compared shocks in budget revenues is especially great. If the fall in oil prices reduces their real value by $19-20 \%$ by $2016-2017$, then the sanctions reduce them insignificantly (by 1-2\%)" (Gurvich \& Prilepsky, 2016). 
The sanctions have caused such consequences as the restriction of foreign lending to the state-owned banks and enterprises of the oil and gas sector and the defense industry complex, the reduction in the inflow of foreign direct investments, the deterioration in borrowing conditions for the companies that have not been sanctioned, and the shortage of advanced technologies and industrial equipment imported from the Western countries. The East Asian countries neighboring with the Far Eastern Federal District (FEFD) supported the sanctions only formally, but did not risk launching new large projects in Russia de facto.

Russia's sharp decline in GDP by 3.7\% in 2015 and a slow transition to the positive dynamics in 2016-2017 (-0.2\% and $1.5 \%$, respectively) led to a natural reduction in the state budget's potential to invest in the regional development. In addition, the priorities of the regional policy have changed: the Crimea and Sevastopol have become the main directions of regional construction. According to the official website, the country's leadership allocated 95.7 billion roubles for the implementation of the state program "Social and Economic Development of the Crimean Federal District for the Period to 2020" in 2015, 148 billion roubles - in 2016, 165 billion roubles in 2017, while the state program "The Far East and the Baikal Region" received 25.2 billion roubles, 37.1 billion roubles and 13.6 billion roubles respectively (Portal of State Programs of the Russian Federation, n.d.).

The specialists of the Ministry of Economic Development of the Russian Federation believe that in the short term a sharp drop in budget revenues will limit the investment opportunities of the state, and the Russian economy, with any development of the international situation, will retain the export and raw material reproduction model: "Therefore, it is impossible to form and expand promising focal points of growth and production with a high share of added value, infrastructure and social facilities that provide the satisfaction of social needs without the active use of the state incitement tools for the supply and demand" (Borisova et al., 2016). Nevertheless, it seems that the government of the Russian Federation has managed to formulate a new approach to the development of the Russian Far East. Further, we analyze its main features.

First of all, Moscow agreed to the separation of the RFE economy within the framework of the all-Russian management mode. The amount of capital attracted to the region was determined as the main indicator of the effectiveness of the announced programs. The large foreign investments are of particular interest. According to the expert estimates, in order the FEFD could achieve the level of economic development equal to Central Russia, it requires investments in the amount of more than 1 trillion US dollar. The United States is almost $75 \%$ of Russia's GDP (Zubov, 2015).

The most ambitious project to solve this problem was the creation of priority development areas (PDA) - the economic area, where the key principles include cardinal deregulation and large-scale tax incentives.

The Federal Law "On the Territories of Advanced Social and Economic Development in the Russian Federation" entered into force on March 30, 2015. The subsequent amendments were made to the Tax, Civil and Land Codes of the Russian Federation. The explanations to the regulatory acts emphasize that it is planned to create more favorable business conditions in the priority development areas than in the ordinary Special Economic Areas (SEA), and the PDA residents will be provided with better conditions for doing business with respect to similar territories operating in the APR. In order to attract business, it is developed a set of tax, customs and administrative preferences (Far East Development Corporation, n.d.):

- reduced tariffs for insurance premiums - 7.6\%;

- accelerated VAT refund procedure (within 10 days);

- decreasing coefficient for the MET (Mineral Extraction Tax) (0 - 0.8) for 10 years;

- income tax for the first 5 years after receiving the first profit from $0 \%$ to $5 \%$, the next 5 years - from $10 \%$; land tax $-0 \%$ for 3 years;

- exemption or reduction of the property, land tax rates;

- preferential rental rates - 0.4 (coefficient from the base rate);

- time reduction spent for inspections (not more than 15 working days);

- financing the infrastructure construction at the expense of the budget and the priority in connecting residents to its facilities;

- free customs area mode: duty-free and tax-free import, storage, consumption of foreign goods within the PDA, re-export of goods;

- lack of permits to attract foreign workers;

- reduction of the terms for obtaining permits: for capital construction - not more than 40 days, for ecological 
examination - not more than 45 days;

- provision of government services by the management company on the PDA territory;

- reduction of energy tariffs for industrial consumers in the Far East to the average Russian level;

- "one window" mode for an investor;

- establishment of a simplified visa entry (electronic visa) for the foreign citizens through checkpoints on the territory of the free port of Vladivostok;

- tax incentives for organizations engaged in the tourist and recreational activities in the Far Eastern Federal District.

In general, during the implementation of a new state policy to accelerate the social and economic development of the Far East, 30 federal laws and more than 150 resolutions and orders regulating the regional development were adopted (Government of Russia, 2017).

By the beginning of 2018, 18 PDAs were officially approved in the FEFD: four in the Primorsky Territory, three in the Amur Region, Sakhalin Region and Khabarovsk Territory, two in Yakutia and one each in the Kamchatka Territory, Chukotka Autonomous District, and Jewish Autonomous Region (Far East Development Corporation, n.d.).

By the spring of 2018, seven out of 18 specified territories may be considered conditional, where the infrastructure facilities necessary for the implementation of production activities have been created or are being created. The remaining PDAs still have promising status. In addition, according to the plans of the Government of the Russian Federation by 2018, it was expected to create not less than 10 globally competitive PDAs with a total volume of attracted investments of 29 billion roubles in the Far East (Open Data of Russia, n.d.).

In the methodological plan, the PDA formation was based on the so-called cluster approach that involves the creation of a local system of interconnected enterprises that mutually complement each other's technological chains. This leads to a reduction in production costs and increased competitive advantages of the business. The cluster is based on the "anchor" investor, who, in effect, determines the specialization of the development territory while ensuring the final product production.

However, the analysis of the PDA Resident Register, posted on the website of the Far East Development Corporation, does not always make it possible to uniquely determine the specialization of a particular cluster (Far East Development Corporation, n.d.). So, the specialization of "Khabarovsk" ODA is formally defined as industrial and transport-logistical. However, the List of Permitted Economic Activities (Government of the Russian Federation, n.d.) identified 53 of them - from the production of agricultural products, chemicals and metallurgy, to crop production, fisheries and educational services. By December 2017, 23 residents had documented their participation in the work of the "Khabarovsk" PDA, whose economic activities are very diverse and do not demonstrate complexity, while the PDA itself appeared to be a collection of random companies that were collected with complete disregard for all planning principles.

Moreover, the speed of practical implementation of both federal and regional obligations to equip the PDAs with the production infrastructure cannot withstand any criticism. Thus, "Nadezhdinskaya" PDA refers to one of the first territories legislatively designed as a priority socio-economic development area. The decision on its creation was issued in 2015. However, after the expiration of a three-year period, the readiness of infrastructure facilities, according to the Deputy Prosecutor General Yury Gulyagin, was only 3-5\% of the required level by early 2018 . It resulted in the loss of time, money, the pace of commissioning the production facilities (The Prosecutor's Office Arranged a Uniform Lambast for Work with the PDAs in Primorye, 2018). Thus, using the example of "Nadezhdenskaya" PDA, we can say that there is a significant time lag since the moment when the status of a "special" territory has been formalized prior to the beginning of its functioning in a given mode. According to our estimates, the distance from the "idea" to its implementation is at least 5-6 years. And this means that if the situation does not change, a significant part of the PDAs, which have been legally registered in 2016-2017, will at best start working in 2023-2024.

In addition to the priority development areas, some active attempts are being made to launch parallel projects that, if successful, can accelerate the regional development. First of all, we are talking about the project "Free Port Vladivostok" (FPV). According to the regulations published by the Ministry of Regional Development of the Russian Federation, the main difference between the FPV and the PDA is the need for the counterparty to open a new business (The State Duma Committee on Regional Policy and Problems of the North and the Far East Considered the Execution of the Federal Budget for 2015, 2016). The Federal Law "On Free Port" came 
into force on October 12, 2015 and initially extended to the territory of 15 municipalities of Primorye. Today, the FPV mode operates in other coastal areas of the Russian Far East: in the Khabarovsk Territory - Vaninsky Municipal District; in the Sakhalin Region - Korsakovsky Urban District and Uglegorsk District; in the Kamchatka Territory - Petropavlovsk-Kamchatsky Urban District; in the Chukotka Autonomous District - Pevek Urban District.

The special economic mode extends to a territory with a population of about 1.7 million people. The list of FPV benefits is as follows:

- reduction of insurance premiums from $30 \%$ (for non-residents) up to $7.6 \%$ for the porto-franco residents;

- income tax is $0 \%$ for the first 5 years, $10 \%$ - for the next 5 years to the regional budget, against $20 \%$ - for the non-residents;

- property tax is $0 \%$ for the first 5 years, $0.5 \%$ - for the next 5 years, against $2.2 \%$ - for the non-residents;

- land tax is $0 \%$ for the first 5 years, against $0.3 \%$ to $1.5 \%$ - for the non-residents;

- accelerated VAT refund procedure within 10 days;

- provision of land plots without bidding and for the agreement duration;

- duty-free and tax-exempt mode of free customs area: import, storage, consumption of foreign goods, export of goods, import of foreign goods;

- simplified visa mode, etc.

In general, the project is actively implemented, but it will take at least a year or a year and a half more to make a more or less objective assessment of its effectiveness and adequacy to local conditions.

A common feature of the above projects, which also characterizes Moscow's new approach to the Far East development, is the transfer of the bulk of investment costs from the state to the private business. Thus, the Far East Development Fund invested about 10 billion roubles in regional projects, thereby ensuring the attraction of 158 billion roubles of private investments in February 2017 (Priority Social and Economic Development Territory, n.d.).

While maintaining all the completeness of management functions that determine the game rules in the new economic and legal conditions, the Government of the Russian Federation cannot overcome the differences and contradictions arising at the level of regional and municipal administrations and various departments. The land issue is particularly acute. In fact, it is the cornerstone of any entrepreneurial initiative, whether it be the residents of the DPAs or the Free Port. The process of obtaining the necessary land increases the planned timeframes for the project implementation and to some extent calls into question the feasibility of business participation in projects because of unworked bureaucratic procedures (Refusal to allocate land plots to residents is sabotage. resident of the free port Aleksey Peremezhko, 2016).

Domination of bureaucratic regulation in the far-eastern regional policy has led to the emergence of numerous managerial institutions, which often duplicate each other. As a rule, these are the state structures that require considerable financing. There is the Far East Development Ministry, the Far East Development Fund, the Far East Development Corporation, the Human Capital Development Agency, the PDA administrations, etc. The bureaucrats began to informally call the entire set as the "Minvostok system".

Moscow gives almost all the key posts in this system to the officials who have manifested themselves in the western part of Russia, and not to local natives. With the same persistence, Moscow pushes the federal officials to the posts of regional governors, using the monopoly of the "United Russia" party in the regional political systems. Most likely, this line is due to Moscow's fear that the local officials will steal the federal investments through the subcontractors close to them. However, the persons appointed from the creature center fall into corruption scandals with no less frequency. The main indicator of their effectiveness is de facto the victories of "United Russia" party in the regional and municipal elections, so even after a clear failure in the regional economy and corruption suspicions, a loyal governor will be guaranteed some quiet place in the center as a political pension. Another line of Moscow - for rejuvenating the regional elite and raising the qualification requirements - has led in practice to the fact that young people with a diploma of "state and municipal management" who do not have experience in the real sector of the economy and do not have authority come to the "Minvostok system" among local landlords (a symbiosis of politicians, businessmen and criminals). Of course, these new officials dream of a career in the capital, do not associate their future with the RFE and see it only as a temporary stage in their careers. 
At the same time, the broad presence of the federal center in all spheres of the socio-economic life of the region does not provide protection against abuse at the local level. At present, the fight against corruption is an important component of Moscow's regional policy in the Far East. The investigation of embezzlement of 5 billion roubles when constructing the Vostochny spaceport (Amur Region) was one of the most significant. Since 2014, the case of the Head of the Construction Directorate in the Far Eastern Federal District of the Administrative Office of the President of Russia is under investigation. According to the Prosecutor's Office, the suspect spent more than 1.1 billion roubles for the inappropriate needs allocated for the oceanarium construction in Vladivostok. In 2015, the governor of the Sakhalin region was detained. On suspicion of receiving a bribe of 5.6 million US dollars. A little bit later, the charges were brought against two of his subordinates. Since 2016, an investigation has been carried out into the case of the mayor of Vladivostok accused of corruption (Patrushev and Trutnev remained extremely unhappy with the state of affairs in the fishing industry of the Far Eastern Federal District, 2016).

According to the Police Department statistics for 2017, more than 4,000 economic crimes were registered in the Far East. The Primorsky Territory, where 1,178 offenses were found this year appeared to be the anti-leader of the criminal rating (24th place in the Russian Federation). The situation in the Khabarovsk Territory (46th place), Amur Region (63rd place), Yakutia (64th place) and Sakhalin Region (65th place) looks somewhat better. The Primorsky and Khabarovsk Territories, as well as the Sakhalin Region, also dominate in corruption. A "cleansing" of the vice-governors in Primorye, a criminal case against the leadership of the scientific institute of fishery "TINRO-Center", was added to the already existing corruption scandals in the region. This list may be supplemented with the arrested chief of the Kamchatka Police Department (for abuse of power), the Deputy Minister of Construction of the Khabarovsk Territory and the Head of the Gosavtonadzor of Primorye, the Deputy Head of Rosmorrechflot (57 million roubles of damage), the Head of the Health Department of the Government of the Jewish Region and his Deputy, the damage from abuse of which amounted to 47 million roubles, when purchasing medical equipment (Without visible changes, 2018).

The frequent manifestations of corruption, of course, worsen the investment image of the Far East and reduce the effectiveness of measures to modernize the regional economy.

Another obstacle to the RFE modernization is the sectoral and territorial structure of the economy, formed back in the days of the USSR. Its main feature is the domination of raw materials industries in the region's economy. The understanding of the need to increase the share of the manufacturing sector has come a long time, but it has not been possible to solve this problem for the entire post-Soviet period. So, if the share of extractive industries in the Far Eastern Federal District was $14.9 \%$ in 2005, it reached $24.3 \%$ in 2010, and this figure rose to $28.6 \%$ in 2015. During the same period, the manufacturing sector grew by $55 \%$, but despite the high growth rates, the disproportion in the GRP structure has shifted even more towards the commodity sector: the share of manufacturing industries accounted for $7.7 \%$ in 2005, 5.3\% - in 2010, 5.4\% - in 2015 (Federal Service of State Statistics, 2017).

The reason for the growth of disproportions is the active promotion of oil and gas projects in the region, which have provided positive dynamics of GRP growth for several years. From 1999 to 2011, the local GRP grew by an average of $5.2 \%$ per year (Gross Regional Product, n.d.). The world economic crisis brought down the commodity markets, which the companies working on the economic growth of the Far Eastern Federal District were working on. As a result, since 2012 the economy of the Far East has entered a recessionary area, and the ideas of strengthening the manufacturing economy in the region have again become relevant. According to most experts, the main obstacle to the development of manufacturing industry is the lack of investments. According to the Rosstat, every inhabitant of the Far East was accounted for an average of 159,183 roubles of investments in the fixed assets (the second place after the Ural Federal District) in 2016, while more than $39 \%$ of them were oriented to the enterprises of the raw material complex. And only $6.5 \%$ of all investments were accumulated in the manufacturing sector. And, this despite the fact that the overall dynamics of investments in the region's economy have a steady downward trend since 2012: 1,060 billion roubles - 2011, 971.4 billion roubles - 2012, 842.4 billion roubles - 2013, 820.1 billion roubles - 2014, 905,087 billion roubles - 2015. Despite the fact that the investment volume is declining mainly due to the extractive industry, it still remains the most highly profitable segment of the Far Eastern economy (Russian Regions, Socio-Economic Indicators, 2017).

The programs approved and implemented by the government of the Russian Federation to stimulate the industrial growth in the RFE are aimed at radically changing the current situation. It is assumed that the tax benefits, simplified administration, a special custom mode will significantly increase the attractiveness and profitability of the regional manufacturing industry and lead to an increase in its share in the economy. To this end, the Russian authorities have organized a large number of international events in recent years. A special 
place in this line is the annual Eastern Economic Forum (EEF) aimed at potential investors.

Within the framework of the first EEF, which took place in September 2015 on the Russky Island in Vladivostok, more than 80 major investment agreements worth more than 1.8 trillion roubles were concluded (The Main Economic Events of 2015 in Primorye, 2016). In 2016, the representatives of government and business signed about 200 agreements worth more than 1.63 trillion roubles at the second EEF. In 2017, the third forum brought 217 agreements worth about 2.5 trillion roubles. The share of foreign investment in 2016 accounted for only $15.8 \%$ (155.6 billion rubles.)

However, during three years of the EEF operation, most of the documents signed have the status of the "memorandum of intent", which is a sort of deferred investment, the real investment of which into business projects in the Russian Far East is under big question. This state of affairs is well illustrated by the Rosstat's statistical data, which determine the investment volume in the economy of the entire Far East (and not just in the PDAs and FPV) at the level of 985.2 billion roubles in 2016 against 1.8 trillion roubles of investments announced at the first EEF in 2015. With almost $25 \%$ of the almost trillion investments coming from the state and municipalities $-19.3 \%$ and $3.9 \%$ respectively. The share of foreign investment accounted for only $15.8 \%$ (155.6 billion roubles) in 2016 (Gross Regional Product, n.d.).

\section{Conclusion}

So, the reasons why Russia's regional policy in the RFE receives a much smaller result than the center counts on (apart from the objective geographic problem of remoteness, complex terrain and climate) are as follows:

1) The disproportion of the region's economy in favor of the commodity sector, the insufficient profitability of doing business in other sectors. Even state corporations do not implement government decisions, if their implementation does not provide them with "normal" profits, for example, as in the case of the RFE gasification;

2) The over-centralization of regional politics and the proliferation of "development bureaucracy" instead of delegating authority to the local authorities and weakening the state regulation;

3) Misunderstanding of the regional specifics by the federal bureaucracy and lack of personal responsibility for the GRP growth;

4) High level of corruption in the implementation of regional policies, which provokes the concentration of nation-wide resources on the construction of critical infrastructure facilities;

5) Instability of financial support for regional policy due to excessively tight monetary policy and an unfavorable international environment;

6) Violation of the recommendations of the cluster theory and the theory of growth poles, the SEA formation in large numbers and with the participation of completely heterogeneous firms.

Despite these reasons, it cannot be denied that Moscow is gradually achieving some result, although it is made slowly, namely: the PDAs are being built, the legal and regulatory framework is growing and improving, the most egregious cases of corruption are being investigated, the use of electronic technologies in the interaction of government agencies and business is expanding. As a result, the foreign investors and governments show an obvious interest in doing business in the RFE. In our opinion, it takes about 10 years from understanding the problem and discussing the options for action before obtaining some particular economic results in Russian conditions. In view of the destruction of the system of territorial and economic planning in post-Soviet Russia, the so-called "development strategies" represent only the unlikely ideals to which Moscow seeks in theory. The FTPs (Federal Target Programs) are more representative, but their execution is far from normal. According to our assessment, it will be good, if the center will perform at least $30 \%$ of the events in 10 years.

In the medium term, we expect a slight increase in GRP of the RFE, the population will be stabilized at the current level. The attention of the federal center to the Far East will continue, which will keep the demography and economy of the region from the further recession, the same will support the interest of business - both Russian and foreign - to search for new instruments for the regional development.

\section{Conflict of interest}

The authors confirm that the data presented does not contain any conflict of interest.

\section{References}

Adda, I. (2015). L'Extreme-Orient russe: un acteur central dans le glissement de la Federation de Russie a l'Est. Global Studies Institute de L'Universite de Geneve. Collection Euryopa, 84, 143.

Blakkisrud, H., \& Rowe, E. W. (2018). Russia's Turn to the East. Domestic Policymaking and Regional 
Cooperation. Cham: Palgrave Pivot. p. 167. https://doi.org/10.1007/978-3-319-69790-1

Borisova, I. Yu., Zamaraev, B. A., Kozlova, I. G., Nazarova, A. G., \& Sukhanov, E. Yu. (2016). Russian Economy under the Yoke of Sanctions and Cheap Oil. Issues of Economics, 7, 5-35.

Far East Development Corporation [Electronic resource]. Retrieved from http://erdc.ru

Federal Service of State Statistics. (2017). Retrieved March 18, 2018, from http://www.gks.ru/free_doc/doc_2017/region/reg-pok17.pdf

Government of Russia. (2017). Decisions Adopted at the Meeting of the Government on December 21, 2017. Retrieved from http://government.ru/info/32207/\#

Government of the Russian Federation. Resolution No. 630 dated June 25, 2015 "On Creation of the Priority Social and Economic Development Territory "Khabarovsk". Retrieved from http://erdc.ru/upload/tor-630.pdf

Gross Regional Product. Federal Service of State Statistics. Retrieved from $\mathrm{http} / / / \mathrm{www} . \mathrm{gks} . \mathrm{ru} / \mathrm{wps} / \mathrm{wcm} /$ connect/rosstat_main/rosstat/ru/statistics/accounts

Gurvich, E., \& Prilepsky, I. (2016). The Impact of Financial Sanctions on the Russian Economy. Issues of Economics, (1), 5-35.

Hill, F., \& Gaddy, C. (2003). The Siberian Curse: How Communist Planners Left Russia Out in the Cold. Brookings Institution Press. p. 240.

Huang, J., \& Korolev, A. (2017). The Political Economy of Pacific Russia. Regional Developments in East Asia. Eds. Cham: Palgrave Macmillan. p. 268. https://doi.org/10.1007/978-3-319-40120-1

Kozlov, L. E., \& Volynchuk, A. B. (2016). Regional Policy of Russia in the Far East in Conditions of Unfavorable External Environment (2014-2016). Oykumena. Regional Studies, 4(39), 24-35.

Kuznetsova, O. V. (2013). Regional Policy of Russia: 20 Years of Reforms and New Opportunities. M.: URSS. p 392.

Kuznetsova, O. V. (2018). "The Eastern Vector" of Russia's Investment Relationships. World Economy and International Relations, (2), 47-56. https://doi.org/10.20542/0131-2227-2018-62-2-47-56

Lee, R., \& Lukin, A. (2016). Russia's Far East. New Dynamics in Asia Pacific and Beyond. Boulder; London: Lynne Rienner Publishers. p. 276.

Malle, S., \& Cooper, J. (2014). The pendulum moves from Europe to Asia. Modernizing Siberia and the Far East. Economic and security issues. Journal of Eurasian Studies, (5), 21-38. https://dx.doi.org/10.1016/j.euras.2013.10.004

Open Data of $\quad$ Russia. $\quad$ Retrieved from http://programs.gov.ru/opendata/7710349494-project35/data-20180417T0001-structure-20141225T0001.x $\mathrm{ml}$

Patrushev and Trutnev remained extremely unhappy with the state of affairs in the fishing industry of the Far Eastern Federal District. (2016). AmurMedia. Retrieved August 3, 2016, from http://amurmedia.ru/news/politics/03.08.2016/522614/patrushev-i-trutnev-ostalis-krayne-nedovolni-sostoya niem-del-v-ribnoy-otrasli-df.html

Pavel, M., \& Olga, P. (2017). Centralization and autonomation as the drivers of socio-economic development of the Russian Far East. Economic and social changes. Facts, trends, forecast, (6), 24-41.

Portal of State Programs of the Russian Federation. Retrieved from http://programs.gov.ru/Portal

Priority Social and Economic Development Territory. Far East Development Ministry of Russia. Retrieved from http://minvr.ru/activities/toser.php.

Refusal to allocate land plots to residents is sabotage. resident of the free port Aleksey Peremezhko. (2016). News VL.ru. Retrieved September 3, 2016, from http://www.newsvl.ru/eef2016/2016/09/03/151138/

Russian Regions, Socio-Economic Indicators. (2017). Collection of Articles. / Rosstat. - M., p. 1402.

Scott, J. C. (1998). Seeing Like a State: How Certain Schemes to Improve the Human Condition Have Failed. Yale University Press. p. 445.

The Main Economic Events of 2015 in Primorye. (2016). PrimaMedia. Retrieved January 7, 2016, from http://primamedia.ru/news/economics/07.01.2016/482330/glavnie-ekonomicheskie-sobitiya-2015-goda-v-pr 
imore.html

The Prosecutor's Office Arranged a Uniform Lambast for Work with the PDAs in Primorye. (2018). PrimaMedia. Retrieved January 14, 2018, from https://primamedia.ru/news/686149

The State Duma Committee on Regional Policy and Problems of the North and the Far East Considered the Execution of the Federal Budget for 2015. (2016). State Duma of the Russian Federation. Retrieved October 14, 2016, from http://www.komitet2-1.km.duma.gov.ru/site.xp/052057124050053054048.html

Tullock, G. (2005). Public Goods, Redistribution and Rent Seeking. Edward Elgar Publishers, p. 153. https://doi.org/10.4337/9781845424688

Without visible changes. (2018). Primorsky and Khabarovsk Territories remain district leaders in terms of the number of economic crimes. Rossiyskaya Gazeta. Retrieved February 22, 2018, from https://rg.ru/2018/02/22/reg-dfo/primore-stalo-liderom-dfo-po-chislu-ekonomicheskih-prestuplenijm.html

Zubarevich, N.V. (2016). Evolution of the Priorities of Russia's Regional Policy. Geographical Issues. Collection 141: Problems of Regional Development in Russia. M.: Kodeks. pp. 151-165.

Zubov, V. (2015). Trillion for Primorye: How is it Possible to Russia not to Lose the Far East. RBC. Retrieved April 28, 2015, from http://www.rbc.ru/opinions/economics/28/04/2015/553e238a9a794718eaf89273

\section{Copyrights}

Copyright for this article is retained by the author(s), with first publication rights granted to the journal.

This is an open-access article distributed under the terms and conditions of the Creative Commons Attribution license (http://creativecommons.org/licenses/by/4.0/). 